\title{
Obtaining the Municipal GDP in Hidalgo. Regional polarization and economic imbalances.
}

\author{
Obtención del PIB municipal en Hidalgo. Polarización regional y desequilibrios económicos.
}

\author{
Maximiliano Gracia Hernández
}

\begin{abstract}
:
Using economic indicators at municipal level is a nearly impossible task. National Institute of Statistics and Geography, Mexico, does not offer statistics on municipal GDP. For this reason, the aim of this work was to obtain data disaggregated at the local level. The main contribution of the research was to calculate the GDP in the 84 municipalities of the state of Hidalgo. The methodology proposed by Luis Unikel was used to achieve this. This methodology argues that it is feasible, to obtain an index of personnel occupied by municipality and, with it, to obtain a consistent series of panel data by municipalities. The Research prove with calculated estimates and data for all municipalities.
\end{abstract}

Keywords:

Hidalgo economy; Gross Domestic Product; Municipal indicators; Polarization economic; Development opportunities.

\section{Resumen:}

Utilizar indicadores económicos a nivel municipal es una tarea casi imposible. El Instituto Nacional de Estadística y Geografía de México no ofrece estadísticas sobre el PIB municipal. Por ello, el objetivo de este trabajo fue obtener datos desagregados a nivel local. El principal aporte de la investigación fue calcular el PIB en los 84 municipios del estado de Hidalgo. Para ello se utilizó la metodología propuesta por Luis Unikel. Esta metodología sostiene que es factible, obtener un índice de personal ocupado por municipio y, con él, obtener una serie consistente de datos panel por municipios. La investigación prueba con estimaciones calculadas y datos para todos los municipios.

\section{Palabras Clave:}

Economía de Hidalgo; Producto Interno Bruto; Indicadores municipales; Polarización económica; Oportunidades de desarrollo.

\section{Introduction}

For those of us who reflect and research regional development issues in Mexico, we are concerned about finding statistics and economic indicators that allow us to evaluate the economies of Mexican municipalities. As they argument Corona F., (2019): ...in order to produce economic information at the municipal level with appropriate timing and sectorial breakdown —which allows decision makers to generate economic-policies.

While there are different geographical and social indicators for diagnosing and assessing the environment, we also observe in the Mexican economic sphere the lack of statistics, for example, of Gross Domestic Product at the municipal level, so it is almost impossible to assess the municipal economic scenario in Mexico and answer the question: how are we in economic matters within Mexican municipalities?

Sustained economic growth in a region, municipality or locality provides the basis for steady and sustained social welfare. Some variables considered as basic to increase social welfare are: the increase in GDP; increase in per capita income; technological changes; sustainable exploitation of natural resources; improving the quality of education and health; greater and better infrastructure; investment in research and development; development of new innovations; etcetera.

\footnotetext{
${ }^{1}$ Colegio del Estado de Hidalgo. http://orcid.org/0000-0003-3174-8006

Correspondence with the author maximiliano@elcolegiodehidalgo.edu.mx ; graciamaximiliano@hotmail.com
} 
The objective of the research aims to obtain municipal GDP in the municipalities of the State of Hidalgo, a Mexican region located in the center of the country. The study object is Hidalgo, because it is the place where is located the research institution.

The initial concern to carry out the work was to determine the causes existing in the municipal and regional polarization within the State of Hidalgo. Phenomenon that is observed empirically in the municipalities, but without having indicators that allow scientifically to check what is happening there.

The methodology used for the calculation of Hidalgo's municipal GDP was quantitative, INEGI statistics were used and INEGl's 2014 Economic Census was considered as the basis.

We make an approach to the discovery of indicators, using information from the primary, secondary and tertiary economic sectors at the municipal level. The methodology used is accurate, because it is close to that used by the National Institute of Statistics and Informatics of Mexico (INEGI).

The objective was to obtain and analyze the GDP generated in each of the 84 municipalities of Hidalgo. It is important to note that the original contribution of the research lies in obtaining GDP in the municipalities of Hidalgo and is that in Mexico there is no official data that calculate this indicator. Disaggregated municipal GDP in Hidalgo represented a breakthrough to economic knowledge in that region. Exist the human development index at the municipal level, however, it is not a variable that shows the GDP generated in a region.

The work is divided into five sections, the first briefly shows the characterization and physical, sociodemographic, human development and infrastructure diagnosis in the state of Hidalgo, Mexico.

The second section presents the methodology used to obtain municipal GDP. The third one shows the results obtained and the discussion generated; the fourth section demonstrates the existence of a strong economic polarization in the 84 municipalities of the state of Hidalgo. The fifth section offers a reflection on the challenges and opportunities of the state of Hidalgo.

Reflecting on the importance of studies and research on local and municipal issues is fundamental in economic science, and that is that regional development needs new strategies to attract investment; generate business competitiveness; identify and implement efficient and effective public policy strategies; implement systemic competitiveness actions and improve the quality of life of people living in the areas farther away from the main economic centers of Hidalgo.

\section{Characterization of the state of Hidalgo}

Hidalgo is one of 31 states that, along with Mexico City, form Mexico's 32 federal entities. The state of Hidalgo has 84 municipalities, its capital and most populated city is Pachuca de Soto. The state is located in the centraleastern region of Mexico, has an area of $20,813 \mathrm{~km} 2$, because its geographical dimension Hidalgo ranks 26th in the Mexican republic, representing $1.06 \%$ of the national territory. As seen on map 1, Hidalgo adjoins to the north with the states of San Luis Potosí and Veracruz, to the east with the state of Puebla, to the south with the states of Tlaxcala and Mexico, and to the west with the state of Querétaro

The state of Hidalgo is composed of 84 municipalities and 3,474 localities (Sedesol, 2018), which are composed of different physical conditions; relief features; economy; social and cultural issues.

\section{Sociodemographic characterization}

According to the last available count (INEGI, 2015) the state of Hidalgo has a population of $2{ }^{\prime} 858,359 ; 2.4 \%$ of the country's total population. Of that population, 1'489,334 are women, and 1'369,025 are men. The population distribution is: $52 \%$ urban and $48 \%$ rural.

The cities of the state considered as most important for their economic and social dynamism are: Pachuca de Soto, Tulancingo de Bravo, Tula de Allende, Tizayuca, Tepeji del Río, Actopan, Apan, Huejutla de Reyes, Ixmiquilpan and, Huichapan. With the exception of Huejutla, all designated municipalities are located in the south-central part of the state.

As seen in map 2, in the southern part of the state there is a high degree of concentration with more than $70 \%$ of the total population, which is equivalent to $2^{\prime} 000,851$; in contrast, in the northern part there is a medium and low population density per $\mathrm{km} 2$, in these municipalities only $30 \%$ of the Hidalgo population is located.

\section{Characterization of human development}

The Human Development Index (HDI) for the state of Hidalgo is high, 0.723 (UNDP, 2015), to note that the municipalities of Tepehuacán de Guerrero, Xochiatipan, Yahualica, Huehuetla and Acaxochitlan have a low HDI, particularly Tepehuacan, Calnali and the Mission are municipalities that show the lowest HDI, as shown in map 3 , all municipalities with the lowest HDI are located in the northern part of the feature. In contrast to the above, 19 municipalities located in the southern part of the state have the highest HDI. Specifically, it is detected that Mineral de la Reforma, Pachuca de Soto, Mineral del 
Monte and Tizayuca, are the municipalities with the highest state HDI (COESPO, 2010).

\section{Road Infrastructure Characterization}

The state of Hidalgo has a road length of $11,573 \mathrm{~km}$; $864.7 \mathrm{~km}$ of railways, a national airport and two airfields. As seen in map 4, there is a polarization in road infrastructure, the northern part of the state has lowquality roads, in contrast, the southern part of the state is federal and quota road passage with adequate conditions, in addition most of the they are four-lane.

\section{Industrial characterization}

As detected on map 5, there is a strong polarization in Hidalgo in the location of industrial parks, all located in the southern part of the state, particularly in the municipalities of Tepeapulco, Mineral de la Reforma, Villa de Tezontepec, Atitalaquía, Atotonilco de Tula, Tizayuca y, Tepejí del Rio. This is a key part of polarized economic growth. The generation of jobs originates mainly in the southern part of the state, this generates migration from the municipalities in which the industry does not arrive.

\section{Research methodology}

Determining the GDP contribution of each of the 84 municipalities of Hidalgo is an urgent and necessary task, and is that today, in the process of competition and globalization, they compete are the regions and municipalities, therefore an original contribution of this research is framed in the determination of the GDP of the 84 municipalities of Hidalgos, these statistics are not so far calculated and therefore implies a challenge to their determination for those who work and investigate economic issues of local development.

There are some studies and methodologies that try to obtain GDP at the municipal level, works such as: Aguilera, M. Et al (2020); Rojas, S., Hugo Roberto (2012). To obtain the disaggregated data at the municipal level, this research is based on Unikel et. al (1976), this methodology argues that it is feasible, with a few training assumptions, to obtain an index of personnel occupied by municipality and, with it, to obtain a consistent series of panel data by municipalities, which can be an efficient indicator of a physical volume index, on which the state value added can be interpolated, in order to separate the component from the state value added, in order to separate the component municipal participation within the state. With this element, it is feasible to separate the municipal share in the formation of state GDP. Which will be the panel data series that will contain an efficient estimator of municipal GDP. It is important to show that this disaggregation has a set of important formative assumptions that are not necessarily true, as is the fact that the average and marginal product of the work is constant, and that the aggregate production function is of type Leontief; however, even with these limitations, the efficiency of the estimates generated in this research is shown, which, by obtaining the sum of the municipal GDP of each of the 84 municipalities of the state, is almost accurately close to the GDP data of Hidalgo calculated by INEGI for the year 2013 and published in the economic censuses of 2014 .

Formula 1 was used to achieve the objective:

$$
\text { 1) } \mathrm{PIBM}=\left(\sum \frac{P O i j}{P O E i} V A B E i\right)+I P N j
$$

Where, POij-population occupied by economic activity and municipality; POEi-state-occupied population by economic activity; VABEi-gross state value added by economic activity; GROSS domestic product by economic activity and municipality; IPNi- net income taxes by economic activity. $\mathrm{I}=1,2,3,4$. . . $\mathrm{n}$ (Economic Activity Sector). $\mathrm{J}=1,2,3,4 \ldots \mathrm{n}$ (municipality number).

\section{Results and discussion}

This section refers to essentially quantitative data on the economy of the state of Hidalgo, the purpose is to have a dimensioning of reality, which reflects the nature, peculiarity and links that originate from economic activities and processes, based on the results obtained with the methodology used.

\section{Main municipalities for contribution to state GDP}

Based on the application of the methodology indicated above and, based on the use of the 2014 economic censuses, the results shown in map 6 were obtained. It shows the contribution of the municipalities to GDP of Hidalgo state. Stands out Pachuca de Soto, a municipality with a high contribution to the GDP generated, follows in importance for contributing to the GDP of the state Tulancingo de Bravo; Mineral de la Reforma, Tizayuca, Tula de Allende and Tepeji del Rio. All the above mentioned municipalities are located in the southern part of the state. In contrast, there are municipalities whose contribution to the GDP generated are of the lowest: Eloxochitlán, Juárez Hidalgo, Xochicoatlán, Pacula, Nicolás Flores and La Misión, the municipalities 
mentioned above are located in the northern region of the state.

Huejutla de Reyes is the only municipality located in the northern region of the state with a GDP above the state average, the rest of the municipalities located in the northern part of the state show low or very low economic growth.

Important to note that the proximity to Mexico City and the industrial zone of the state of Mexico does not necessarily guarantee high levels of growth, and it is that, if you look at map 6 , of the eleven municipalities adjoining the state of Mexico, only three of them show high levels of growth, the rest offer low or very low economic growth. In addition, it is worth noting that, of the seven neighboring municipalities with the state of Querétaro, none of them offers high economic growth, in the case of Huichapan is shown an average growth, Tecozautla and Zimapán offer low growth; the rest of the municipalities have very low growth. Based on the above, the lack of industrial chains of the municipalities of Hidalgo, adjoining other states that show high economic growth, can be inferred; an opportunity that has so far not been exploited to generate economic osmosis in each of the Hidalgo's regions.

As seen in map 6, there are six municipalities that have high and very high GDP, highlight Pachuca de Soto, Mineral de la Reforma, Tizayuca, Tepeji, Tula de Allende and Tulancingo, all located in the southern part of the state; in contrast, almost all municipalities located in the northern part of the state show a low or very low contribution to state.

When considering GDP by municipalities in the state of Hidalgo, we realized the strong polarization existing in GDP generation: Pachuca de Soto, Tulancingo de Bravo, Mineral de la Reforma, Tizayuca, Tula de Allende and Tepeji del Rio de Ocampo were the municipalities with the greatest contribution to GDP during 2014, contributed $40.1 \%$ to the state's. The rest of the GDP is contributed by the remaining 78 municipalities.

Of the six municipalities mentioned above: Mineral de la Reforma; Tizayuca; Tula de Allende and Tepeji del Rio have industrial parks, this shows a relationship between industrial infrastructure and contribution to the GDP of the state.

If we consider the GDP generated by the main fifteen municipalities (out of a total of 84), these generated 60.5 percent of the state, in addition to considering that all of them (with the exception of Huejutla, Ixmiquilpan and Huichapan) are located in the south of the State. In contrast to the above, it is found that the 30 municipalities with the least contribution to the state's GDP generated only $7.9 \%$ of the total GDP

\section{Pachuca, a leading municipality in the state economy}

Pachuca de Soto maintains a very high share within the state economy, providing $13.6 \%$ of state GDP. The municipality is characterized by its strength in the services sector, it contributed to municipal GDP 27,648 million pesos, which is equivalent to $78.41 \%$ of municipal GDP. Pachuca is a municipality of services and represents a leading economy in Hidalgo, its economic growth is a great determinant of the GDP generated in Hidalgo, this municipality is the only one to generate more than $13 \%$ of the state GDP.

The municipality has very interesting and important competitive advantages for the state economy, for example, young population with good educational level, strategic location; public safety; universities and research centers, the largest offer of services and infrastructure, good business environment, strategic geographical location, etc. Variables that partly allow it to have economic importance within the state.

The municipality of Pachuca de Soto contributed to the GDP of the state more than the rest of the 83 municipalities. In 2014, Pachuca de Soto contributed to GDP 27,648 million pesos, followed in importance Tulancingo de Bravo with 18,461 million pesos and Mineral de la Reforma with 17.281 million pesos.

Pachuca de Soto represents the largest economy of the State, however, the challenges are broad, for example, it is necessary to generate greater innovative projects that will strengthen the project called: "Pachuca, city of knowledge and culture"; attracting companies, commercial relations with foreigners, strengthening and implementing ecological zones for the city, etc.

\section{Tulancingo de Bravo. Second municipality in economic importance}

Tulancingo contributed $7.13 \%$ to state GDP; the main economic sector is the tertiary sector, which contributes $68 \%$ to the economy; is followed in importance by secondary with $30.72 \%$.

Tulancingo has eleven tianguis, two Diconsa stores, and eight Liconsa dairy; four public markets, a slaughterhouse and a Wholesale Market, this allows a good distribution of food for the whole region as it is a municipality near the Sierra Gorda, which provides food to the Wholesale Market located in that municipality. 
The PEA of the municipality amounts to 66,937 people, of whom 61,894 are occupied and 5,043 are unoccupied. Tulancingo's economy is based on the tertiary sector, however, the secondary sector has strengths, particularly with its textile and clothing industry. Tulancingo contributes $16.5 \%$ to the state's GDP, highlighted for its contribution to state, the secondary sector with $6.4 \%$ and the tertiary with $7.8 \%$.

\section{Mineral de la Reforma. Third municipality for economic importance.}

This municipality contributes $6.68 \%$ to the GDP of the state; is important in the municipal economy to tertiary sector, which contributes $79 \%$ and the secondary sector $20.8 \%$.

The municipality has an industrial park in which different types of industries are located, particularly manufactures. As far as trade is concerned, there are 10 tianguis, and thirteen Liconsa stores; four markets and a municipal slaughterhouse.

According to figures from the INEGI Economic Census, the municipality's PEA amounted to 68,314 people, of whom 56,230 are occupied and 12,084 unoccupied. It is a municipality adjoining the capital of the state, is part of the metropolitan area of Pachuca, and is important for the industrial park there installed.

\section{Tula de Allende: Fourth municipality for contribution to GDP.}

Its share of state GDP is $4.32 \%$. The tertiary sector, which contributes $57 \%$ and $40.98 \%$ to the Hidalgo economy, is important in the municipal economy. In the municipality there are industries of transformation, extractives, construction, and maquiladoras.

The most important industries are: the Francisco Pérez Ríos Thermoelectric Plant and the Petróleos Mexicanos Miguel Hidalgo refinery, the Tula, the Cruz Azul Cementera Factory and the Tolteca.

As for the oil industry, the Miguel Hidalgo refinery is installed. It is one of the main municipalities that contribute to the secondary sector of the state economy

\section{Fifth municipality in economic importance: Tizayuca}

The municipality contributes $4.40 \%$ to the state GDP, the tertiary sector has importance in the economy of the municipality, contributes $61.76 \%$ and the secondary sector $37.80 \%$. It has four tianguis, two Diconsa stores and 10 Liconsa dairy shops; plus three public markets, and a slaughterhouse.
In Tizayuca there is an industrial park within which there are different types of industries, highlight the dairy industry; concrete railway sleepers, resins and chemicals, luminous profiles, paints and solvents, integral kitchens, plastics and die-cuttings, commercial furniture and equipment, structures, ceramics, clothing, glass packaging, asphalt emulsions, soaps, pumps, water proofers and hardware.

Tizayuca represents an important region in industrial matters, it is one of the main municipalities attracting industries; the experience of its workforce brings about 50,000 workers to its industrial zone; close to the state of Mexico and Mexico City: the communications infrastructure there installed and the industrial park built ex profeso for the development of manufactures are important elements for the origin and municipal development. However, the competitive and comparative advantages mentioned above keep it as the sixth state economy.

\section{Sixth municipal economy: Tepeji del Rio de Ocampo}

The municipality participates in the contribution to state GDP $3.97 \%$, has importance in the municipal economy the secondary sector, which generates $50.86 \%$ for the economy, and the tertiary sector $48.02 \%$.

This municipality stands out for its strength in the manufacturing industry, however, it has not been able to take advantage of its geographical location and, is that the Municipality of Tepeji del Río is located in the south west area of the State, represents an obligatory step to reach the north of the country through the important MexicoQuerétaro highway, which crosses the municipality and connects with two of the most important industrial areas of the country: the industrial zone of Querétaro and the of State of Mexico; it is also important its strategical location, close to the largest market in the country. However, the comparative advantages of its geographical location have not been used to improve its economic environment.

\section{Economic polarization in Hidalgo}

In contrast to the municipalities previously analyzed; highlight Eloxochitlán; Juarez Hidalgo; Pacula; Nicolás Flores; Xochicoatlán; and La Mision, municipalities with the least contribution to state GDP, however, have a high degree of marginalization, which can be explained by three variables: municipal public expenditure; remittances received and undeclared income.

a) Eloxochitan. The municipality contributes $0.04 \%$ to the state GDP, as would be logical in this type of municipalities, none of its sectors has 
importance in the state economy. The degree of marginalization in Eloxochitlán is average, which is explained from four variables compared to the state average: 1) population of 15 years or more without elementary education (30.95 in the municipality against 18.13 in the state); 2) Homes with some level of overcrowding (30.46 municipal vs. 28.17 state); 3) Income with up to two minimum wages (70.5 municipal vs. 46.22 state); 4) marginalization rate (0.06158 municipal vs. 0.4955 state) (CONAPO, 2015).

b) The municipality of Juárez Hidalgo participates in state GDP with $0.06 \%$, the degree of marginalization in Juárez Hidalgo is average, which is explained from four variables compared to the state average: 1) population of 15 years or more without elementary education (34.88 municipal versus 18.13 state); 2) Homes with some level of overcrowding (27.58 municipality vs 28.17 state); 3) Income with up to two minimum wages (59.17 municipal vs. 46.22 state); 4) marginalization rate $(-0.02514$ municipal vs. 0.4955 state) (CONAPO, 2015).

c) Pacula participates with $0.14 \%$ of state GDP, has a high degree of marginalization, which is explained from four variables compared to the state average: 1) population aged 15 years or over without elementary education (38.82 municipal versus 18.13 state); 2) Homes with some level of overcrowding (32.12 municipal vs. 28.17 state); 3) Income with up to two minimum wages (54.66 municipal vs. 46.22 state); 4) marginalization rate $(0.38061$ municipal vs. 0.4955 state) (CONAPO, 2015).

d) Nicolás Flores participates in the contribution to state GDP with $0.14 \%$. It has a high degree of marginalization, which is explained from four variables compared to the state average: 1) population 15 years or older without elementary education (29.33 municipal versus 18.13 state); 2) Homes with some level of overcrowding (27.4 municipal vs. 28.17 state); 3) Income with up to two minimum wages (69.57 municipal vs. 46.22 state); 4) marginalization rate (0.32113 municipal vs. 0.4955 state) (CONAPO, 2015).

e) The municipality of Xochicoatlán contributes $0.13 \%$ to the state GDP, has an average degree of marginalization, which is explained from four variables compared to the state average: 1) population of 15 years or more without elementary education (28.29 municipal versus 18.13 state); 2) Homes with some level of overcrowding (35.54 municipal vs. 28.17 state); 3) Income with up to two minimum wages (69.2 municipal vs. 46.22 state); 4) marginalization rate (0.08004 municipal vs. 0.4955 state) (CONAPO, 2015).

f) The municipality of La Misión contributes $0.17 \%$ to the state GDP, presents a high degree of marginalization, this is explained from four variables compared to the state average: 1) population of 15 years or more without elementary education (42.63 municipal versus 18.13 state); 2) Homes with some level of overcrowding (35.16 municipal vs. 28.17 state); 3) Income with up to two minimum wages (61.13 municipal vs. 46.22 state); 4) marginalization rate (1,03465 municipal vs. 0.4955 state) (CONAPO, 2015).

As shown in map 6, the municipalities with the lowest contribution to the state's GDP are: Eloxochitlán, Juárez Hidalgo, Xochicoatlán, Pacula, Nicolás Flores, and La Misión. The characteristic among them, in addition to their low contribution to GDP, is the neighborhood with a common border (with the exception of Pacula and La Mission).

As noted in Table 1, not necessarily a low degree of contribution to the GDP of the state generates a high degree of marginalization, it is the case of Eloxochitlán; Juárez Hidalgo and Xochicoatlán, is probably the result of the supports and social development programs received by the government; remittances from abroad and the commitment of its people to development.

The information presented confirms the strong economic inequalities between municipalities. The difference in GDP between the poorest municipality, Eloxochitlán, and the richest, Pachuca de Soto, is expressed by a difference of 313 times.

How have well-evolving municipalities base their growth? The answer lies in the strength of the secondary and tertiary sector, particularly construction, manufacturing, transport, communications, warehousing and financial services. Given the multiplier effects it has on the rest of the production sectors, construction has been a nodal part.

Sector analysis shows the state's approach. It is noted that the tertiary sector represents the main economic activity generating $61.67 \%$ of the state's GDP, the 
secondary sector contributes $34.12 \%$ and the primary sector $4.20 \%$.

In 71 municipalities the tertiary sector stands out and in thirteen municipalities stands out for its contribution to municipal GDP the secondary sector. That is why we confirm Hidalgo as a state with greater strengthening within the tertiary sector, this represents an economic risk as this sector is a generator of low added value and, therefore, of state GDP with strength and consistency in the long term.

If we consider the GDP per municipal capita, based on the data generated by this research, a strong polarization is detected between the 84 municipalities of the state, the 10 municipalities with the highest GDP per capita are: Zapotlán de Juárez (132,073); Pachuca $(127,116)$; Actopan (124,784); Atitalaquia (118,678); Tepejí del Río $(117,560)$; Progreso de Obregón $(116,168)$; Santiago Tulantepec (115,799); Mineral de La Reforma (115,075); Tulancingo de Bravo (114,616); Mineral del Monte $(114,334)$. In contrast to the above, the municipalities with the lowest levels of GDP per capita within the state are: Xochiatipan $(28,982)$; Yahualica $(31,844)$; Tepehuacan de Guerrero (35,072); Tianguistengo (39,150), Calnali $(41,227)$; Eloxochitlán $(42,222)$; Huehuetla $(42,545)$; La Misión (42,569); Xochicoatlán (43,916).above, the municipalities with the lowest levels of GDP per capita within the state are: Xochiatipan $(28,982)$; Yahualica $(31,844)$; Tepehuacan de Guerrero (35,072); Tianguistengo $(39,150)$, Calnali $(41,227)$; Eloxochitlán $(42,222)$; Huehuetla (42,545); La Mision (42,569); Xochicoatlán $(43,916)$.

Figure II shows the five municipalities with the highest GDP per capita, in contrast to the five municipalities with the lowest GDP per capita, we can see that the difference between the highest and lowest is 103 thousand pesos.

\section{Challenges and opportunities}

This section aims to detect the main potentials, limitations and problems that exist to detonate the growth and economic development of the Territory of Hidalgo State.

Hidalgo is a state with great challenges, but also with huge opportunities, for example, its strategic position makes it a privileged region, the entity is located a few kilometers from the main trading center of the country, the city of Mexico; major industrial cities near the state capital, for example: Mexico City at $91.9 \mathrm{~km}$; Tlalnepantla at 95.5 km.; Naucalpan at 99.4 km.; Puebla at 148 km.; Toluca at $172 \mathrm{~km}$; Querétaro is $224 \mathrm{~km}$ from the property. Polytechnic and technology universities are available; research centers; young and skilled labor, et cetera.

Hidalgo is a state with excellent connectivity to the main ports of the country, has highways and federal roads that make it a region with easy connectivity to other major cities of the country.

By region and municipalities, for example, there is the possibility of creating a dairy basin in the municipality of Tizayuca. In Huasteca there are producers of fruits and vegetables, which can be organized to generate productive chains and with it give added value to the products that are planted and harvested there.

Hidalgo has important companies within the mechanical metal branch, stands out internationally renowned companies such as: Dina-Camiones, Bombardier Transportation, Gunderson-Concarril. Companies that can be provided with services and supplies through small and medium-sized firms.

The existence of cement companies in the state (Cemex and Cruz Azul), make the entity the first in Mexico by the number of cement plants installed. In addition to this, Hidalgo is characterized by being a mining economy, it has companies like Real del Monte y Pachuca and the company Minera Autlan.

In the textile and clothing industry, particularly in the Municipality of Tulancingo, this industry is important in which bedding, clothing, cotton yarn and synthetic fibers, flat fabrics, etc. are produced. Based on Hidalgo's historical career within this industry, there is currently the National Center for Textile-Dress Innovation, located in Ciudad del Conocimiento y la Cultura (The City of Knowledge and Culture).

Emphasize the construction in the municipality of Apan of a bottler of the Modelo group, with an investment of 14 billion pesos and the creation of 1,200 direct jobs.

Emphasize the competitive and comparative advantage that several municipalities of Hidalgo have at tourist offer, highlight the archaeological areas, the water parks, the adventure tourism, the mining and fishing districts, the magical villages, etc., all they are located at different points of the state and are a fundamental element in detonating economic growth within the different Regions of Hidalgo.

\section{Final Reflections}

Beyond the determination of the municipal growth indicators obtained in this research, a polarization between the state's municipalities is observed in Hidalgo. This could be the result of different factors within which they stand out: rugged physical conditions in the northern part of the state, in contrast to the plains and wide valleys of the southern part of the state; regional and municipal polarization in existing infrastructure, particularly in communications, industries and services.

Polarized regions imply a continuation of existing fragmentation. This leads to regions with high growth 
versus regions showing mediocre growth and development.

INEGI (2014) evidence the polarization between the south and north of the state of Hidalgo, some of them are unemployment; emigration; low-quality educational offering; insufficient health centers; poor communications infrastructure; high marginalization rates; etcetera. Based on the above, there is the origin and conditions for the existence of regional imbalances in the state.

The objective of the research, although it was to obtain the municipal GDP of Hidalgo, this did not limit the concern to affirm the need to break with the polarization existing in the state, for this a number of public policy strategies are required, infrastructure, which breaks the negative spiral of poverty, marginalization and underdevelopment in the different municipalities of Hidalgo.

Haga clic o pulse aquí para escribir

texto.

\section{Annex 1}

Map 1. Location of the state of Hidalgo in Mexico

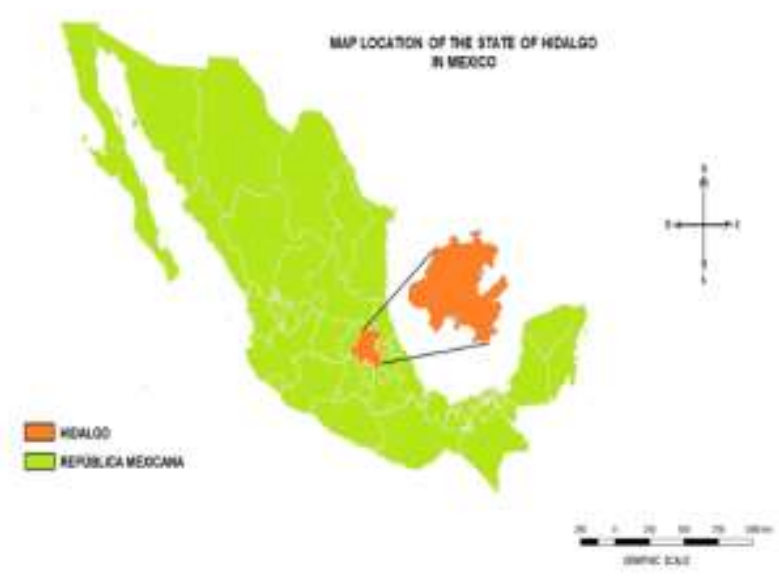

Source: Own elaboration based on Digital Map of Mexico, INEGI (2018). Using the ArcGIS program 
Map 2. Population density in the municipalities of Hidalgo.

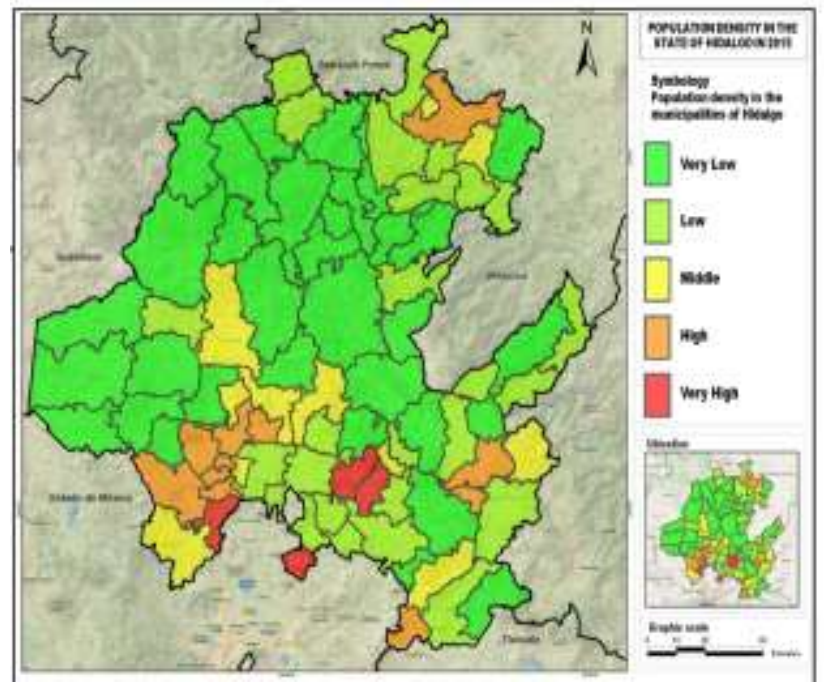

Source: Own elaboration with population and housing count 2015 data.

INEGI (2015). Using the ArcGIS program 
Map 3. Human Development Index in Hidalgo State

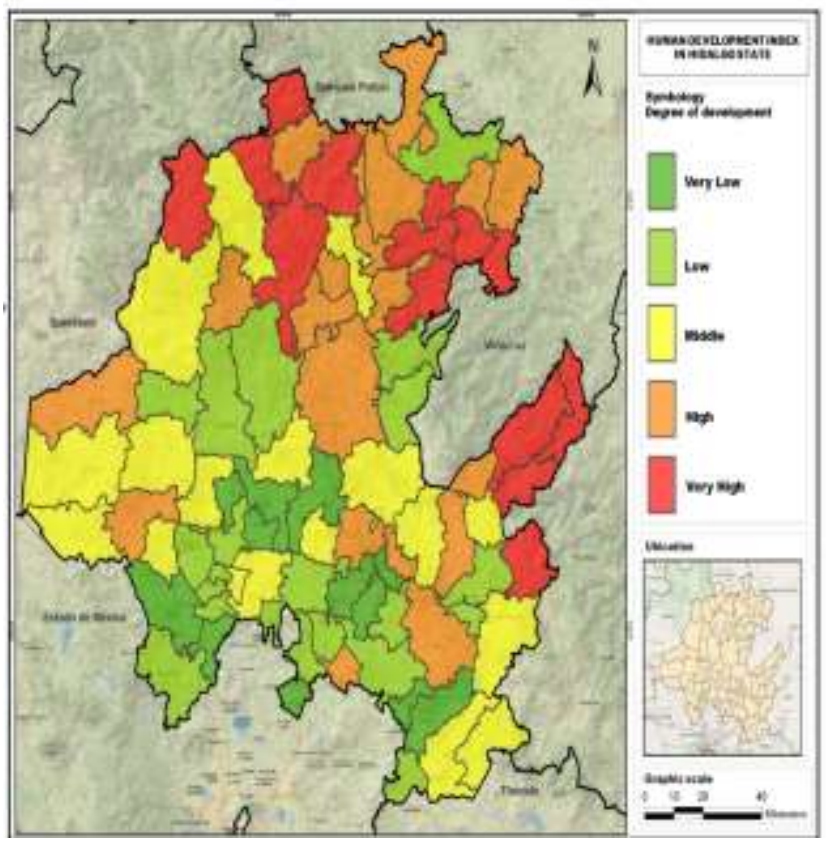

Source: Own elaboration with data from municipal (2010). Using the ArcGIS program
Map 4. Federal and state roads in Hidalgo state

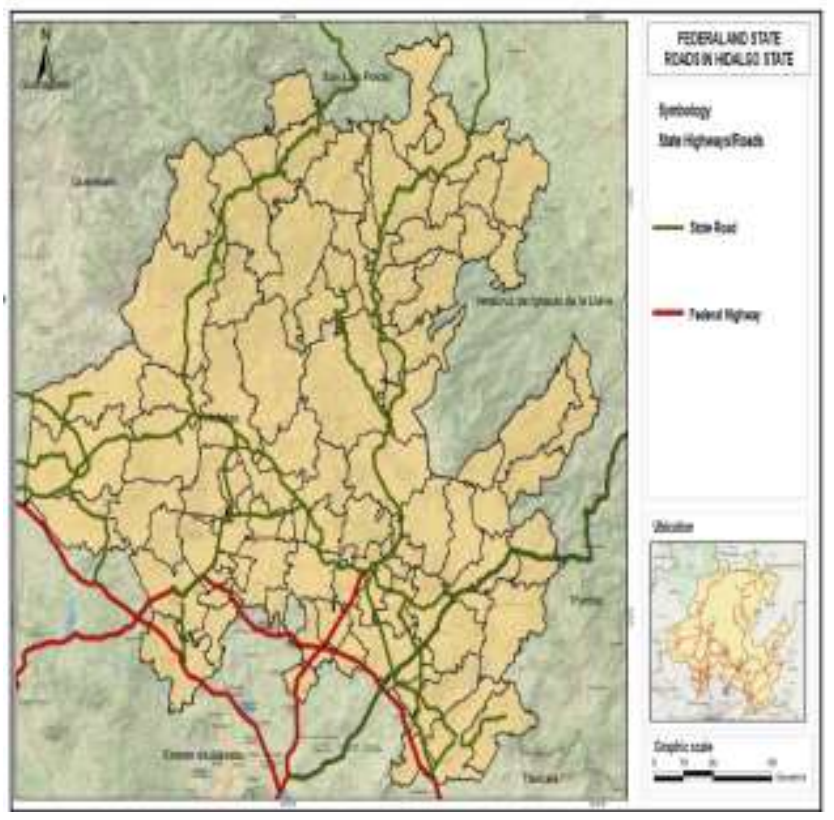

Source: Own elaboration based on Secretary of Communications and Transport (2017). General direction of roads. Using the ArcGIS program 


\section{Map 5. Location of industrial parks in Hidalgo state}

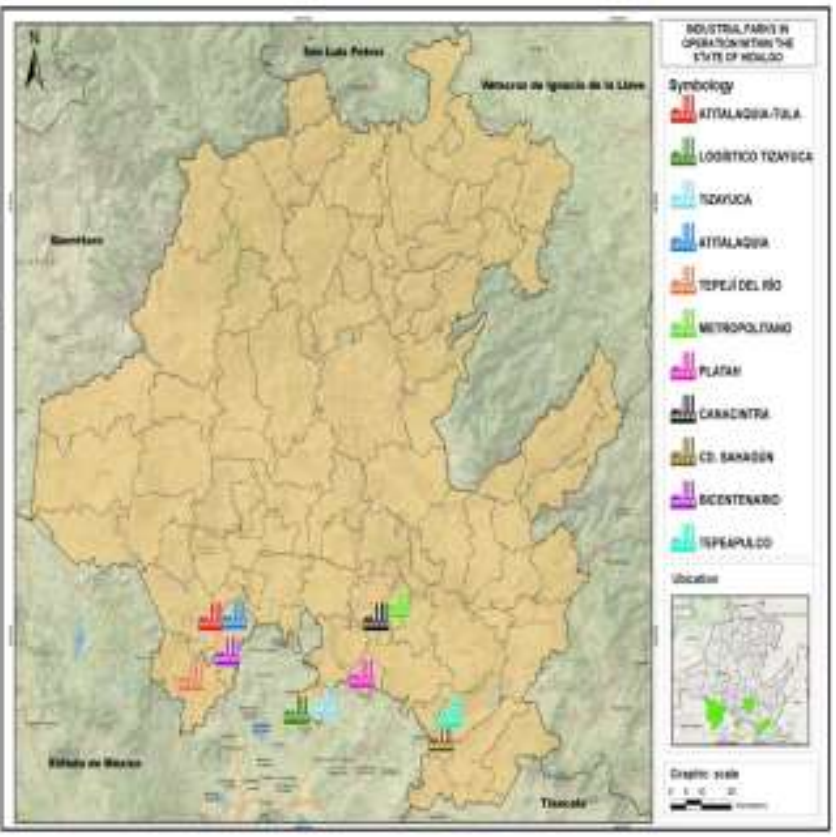

Source: Own elaboration based on Economic and State Information, Secretariat of the Economy $(\mathrm{S} / \mathrm{F})$. Using the ArcGIS program.

Map 6. Gross Domestic Product in the Municipalities of Hidalgo (2014)

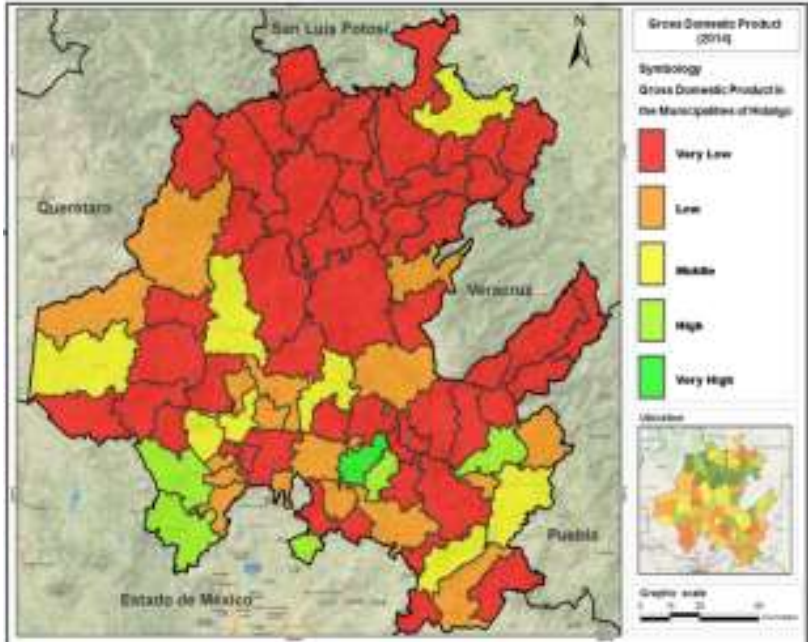

Source: Elaboration based on own indicators generated from Economic Census, INEGI (2014). Using the ArcGIS program

Figure 2:

GDP per municipal capita in Hidalgo Municipalities with higher and lower indicator
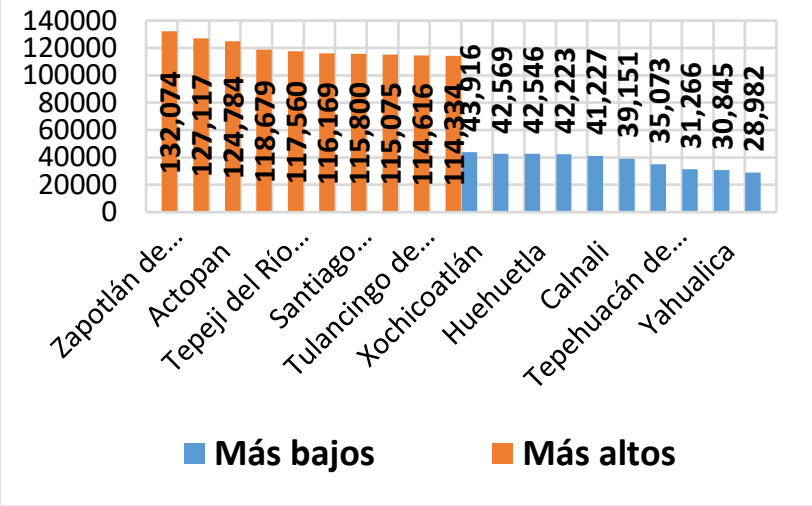

Source: Own elaboration based on data generated in the research and Intercensal survey INEGI (2015).

\section{Referencias}

[1] Aguilera, M. Et al (2020) ¿Cambia la productividad en el territorio? Una propuesta metodológica para la estimación del PIB urbano en la 
economía española, in Investigaciones Regionales ISSN 1695-7253, No. 47, págs. 79-95

[2] COLEH 2014. "Hidalgo Territorial Planning Plan" (Plan de Ordenamiento Territorial de Hidalgo), Working Paper s/n, Hidalgo State College, Hidalgo, Mexico

[3] COESPO (State Population Council) 2010. "Municipal Human Development Index of Hidalgo" (Índice de desarrollo Humano Municipal), Hidalgo, México, [online] http://poblacion.hidalgo.gob.mx/?p=1528

[4] CONAPO (National Population Council) 2015. "Hidalgo Index and Degree of Marginalization", [online] http://poblacion.hidalgo.gob.mx/?p=1409

[5] Corona, F., Jesús López (2019), Obteniendo indicadores de actividad económica municipal basados en información representativa de los Censos Económicos, Revista Realidad, datos y espacio, INEGI, Vol. 10, Núm. 2, mayo-agosto.

[6] Moreno L. (2013) Cálculo del PIB Municipal para el Estado de Sonora. Revista Auditoría Gubernamental No. 32 (julio-septiembre).

[7] INEGI (National Institute of Statistical Geography and Computer Science) 2018. "Digital Map of Mexico" [online] http://gaia.inegi.org.mx/mdm6/?v=bGF0OjIzLjMyMDA4LGxvbjotM TAxLjUwMDAwLHo6MSxsOmMxMTFzZXJ2aWNpb3N8dGMxMT FzZXJ2aWNpb3M

[8] INEGI (a) (National Institute of Statistical Geography and Computer Science) 2016. "Mexico in numbers", [online] https://www.inegi.org.mx/app/areasgeograficas/?ag=13.

[9] INEGI, (National Institute of Statistical Geography and Computer Science) 2016. "GDP federal entity", [online] http://www.inegi.org.mx/est/contenidos/proyectos/cn/pibe/

[10] INEGI (National Institute of Statistical Geography and Computer Science) 2015. "Main Results of the 2015 Hidalgo Intercensal Survey", [online]

http://internet.contenidos.inegi.org.mx/contenidos/Productos/prod_ser v/contenidos/espanol/bvinegi/productos/nueva_estruc/inter_censal/esta dos2015/702825079789.pdf

[11] INEGI (National Institute of Statistical Geography and Computer Science) 2014. Economic Census, [online] Available: http://www.inegi.org.mx/est/contenidos/proyectos/ce/ce2014/default.a spx

[12] INEGI (National Institute of Statistical Geography and Computer Science) 2014. Estructura económica de Hidalgo.

[13] Rojas, S., Hugo Roberto (2012). Una década de participación del Producto Interno Bruto de Puerto Vallarta al estado de Jalisco, 20002009, revista Investigación y Ciencia, vol. 20, núm. 54, enero-abril, pp. 30-39

[14] UNDP (United Nations Development Programme) 2015. "Human Development Index for Federal Entities, Mexico 2015", [online] http://www.mx.undp.org/content/dam/mexico/docs/Publicaciones/Pub icacionesReduccionPobreza/InformesDesarrolloHumano/PNUD_bolet inIDH\%20final.pdf

[15] SCT (Secretary of Communications and Transport) 2017. "National Road Conservation Program 2017" [online] http://www.sct.gob.mx/carreteras/direccion-general-de-conservacionde-carreteras/avance-del-programa-de-obra-2017/hidalgo/

[16] SE (Secretary of Economy) 2018. "PROMÉXICO Investment and Commerce", [online] http://mim.promexico.gob.mx/work/models/mim/Documentos/PDF/mi m/FE_HGO_vf.pdf

[17] SE (Secretary of Economy) S/F. "Economic and State Information. Hidalgo",

[online] https://www.gob.mx/cms/uploads/attachment/file/124836/hidalgo.pdf

[18] SEDESOL (Secretariat for Social Development) 2018. "National State Directorate-General Management of Productive Options", [online]
http://www.sedesol.gob.mx/work/models/SEDESOL/Programas_Socia les/OpcionesProductivas/MapaTematico/CoberturaNacional201

[19] SIAP, (Agri-Food and Fisheries Information Service 2015. "Sowing and Harvesting" National summary by state, [online] http://infosiap.siap.gob.mx:8080/agricola_siap_gobmx/AvanceNacion alCultivo.do

[20] Unikel L. et al. 1978. Mexico's urban development: diagnostics and future implications,[online] http://www.cervantesvirtual.com/obra/eldesarrollo-urbano-de-mexico-diagnostico-e-implicaciones-futuras924525/ 